\title{
Pengaruh Implementasi Metode Problem Based Learningterhadap Hasil Belajar MateriKeluarga Berencana (Dalam Mata Kuliah Kesehatan Reproduksi dan KeluargaBerencana I pada Program Studi Kebidanan (D-III) STIKes Jenderal Achmad Yani Cimahi TA.2014/2015)
}

\author{
Rani Sumarni, ${ }^{1}$ Ponpon S. Idjradinata, ${ }^{2}$ Ike R. Husen, ${ }^{3}$ Farid Husin, ${ }^{4}$ TitaH. Madjid, ${ }^{5}$ Hadyana Sukandar ${ }^{6}$ \\ ${ }^{1}$ Mahasiswa Program Studi Kebidanan Fakultas Kedokteran Universitas Padjadjaran \\ ${ }^{2}$ Departemen Ilmu Kesehatan AnakFakultas Kedokteran Universitas Padjadjaran \\ ${ }^{3}$ Departemen Ilmu Farmakologi dan Terapi FakultasKedokteranUniversitasPadjadjaran \\ ${ }^{4}$ Departemen EpidemiologidanBiostatistika Fakultas Kedokteran Univeritas Padjadjaran Bandung \\ ${ }^{5}$ Departemen Obstetri dan Ginekologi Fakultas Kedokteran Univeritas Padjadjaran \\ ${ }^{6}$ Departemen EpidemiologidanBiostatistika Fakultas Kedokteran Univeritas Padjadjaran Bandung
}

\begin{abstract}
Abstrak
Bidan memegang peranan penting dalam memberikan pendidikan dan pelayanan kepada masyarakat khususnya dalam pelayanan Keluarga Berencana (KB). Salahsatu upaya yang dapat dilakukan guna menghasilkan bidan yang berkualitas adalah dengan peningkatan kualitas program pendidikan bidan melalui penerapan Kurikulum Berbasis Kompetensi (KBK).Problem Based Learning (PBL) merupakan bagian dari strategi KBK yang menggunakan masalah dunia nyata sebagai dasar pembelajaran peserta didik, sehingga diharapkan dapat berpikir kritis, memiliki keterampilan pemecahan masalah, serta memperoleh pengetahuan dan konsep esensial dari materi perkuliahan. Tujuan penelitian ini adalah untuk mengetahui pengaruh implementasi PBL terhadap hasil belajar mahasiswa serta kaitannya dengan Indeks Prestasi Semester I, Self Directed Learning (SDL) dan kinerja tutor.Metode penelitian ini menggunakan rancangan pre-eksperimental dengan pendekatan kuantitatif, menggunakan desain Intact Group Comparison, terdiri dari dua kelompok penelitian, yaitu kelompok perlakuan (PBL) dan kelompok kontrol (non PBL). Penelitian dilakukan di STIKes Jenderal Achmad Yani Cimahi pada bulan Februari-Maret 2015. Sampel sebanyak 120 mahasiswa Semester II, terbagi dalam 3 kelas, yang terdiri dari 1 kelas sebagai kelompok perlakuan dan 2 kelas sebagai kelompok kontrol. Analisis data melalui uji t tidak berpasangan, Mann-Whitney, regresi berganda, dan Korelasi Pearson. Kemaknaan hasil uji ditentukan berdasarkan nilai $p<0,05$. Hasil penelitian menunjukkan bahwaterdapat pengaruh metode PBL terhadap nilai ujian tulis materi KB dengan mempertimbangkan faktor IP Semester sebelumnya (IP Semester I) $(p=0,001)$, tidak terdapat pengaruh metode PBL terhadap SDL $(p=0,548)$, tidak terdapat hubungan bermakna antara kinerja tutor dengan nilai ujian tulis materi $\mathrm{KB}(p=0,360)$, terdapat hubungan bermakna antara kinerja tutor dengan kemampuan SDL mahasiswa $(p<0,001)$, dengan nilai korelasi 0,559 yang menunjukkan korelasi positif dengan kekuatan korelasi sedang.Simpulan bahwa Implementasi metode PBL berpengaruh terhadap nilai ujian tulis, metode PBL tidak berhubungan dengan kemampuan SDL mahasiswa, kinerja tutor tidak berhubungan dengan nilai ujian tulis, namun berhubungan dengan kemampuan SDL mahasiswa. Perlu disempurnakannya penerapan metode PBL pada materi KB, serta meningkatkan pelaksanaan tutor training yang lebih optimal, intensif, dan berkesinambungan.
\end{abstract}

Kata Kunci :Hasil belajar, nilai ujian tulis, kinerja tutor, problem based learning,self directedlearning

Korespondensi :Jl. Eijkman No.38 Bandung 40161, Indonesia, Hp. 081324178336, e-mail: bidanrani@ymail.com 
Rani Sumarni: Pengaruh Implementasi Metode Problem Based Learning terhadap hasil belajar materiKeluarga Berencana (Dalam Mata Kuliah Kesehatan Reproduksi dan KeluargaBerencana I pada Program Studi Kebidanan (D3) STIKes Jenderal Achmad Yani Cimahi TA.2014/2015)

\title{
The Influence of Problem Based Learning Method Implementation to Learning Outcomes of Family Planning Materials (in Course of Reproductive Health and Family Planning I on Midwivery Program (D-III) Stikes Jenderal Achmad Yani Cimahi 2014/2015)
}

\begin{abstract}
Midwives play an important role in providing education and public services, especially in the service of Family Planning (FP). One of the main efforts that could be done in order to produce a qualified midwife is to improve the quality of midwifery education programs through the implementation of competency-based curriculum (CBC). Problem Based Learning (PBL) is part of the CBC that uses real-world problems as a basis for the learning of students, which are expected to think critically, have problem solving skills, also acquire knowledge and essential concepts of lecture material. The purpose of this study was to determine the effect of the implementation of PBL on student learning outcomes and its relation to First Semester IP (Grade Point Average/GPA), Self Directed Learning (SDL) and the performance of tutor. This research method is using Pre-Experimental design with a quantitative approach, using Intact Group Comparison design, consists of two research groups, that is the treatment group (PBL) and the control group (non-PBL). The study was conducted in Stikes Jenderal Achmad Yani Cimahi in February to March 2015. The total sample is 120 students of the Second Semester, which are determined randomly the groups were devided into research group (1 group) and control group ( 2 groups). Analysis of the data is using the unpaired $t$ test, Mann-Whitney, Multiple Regression and PearsonCorrelation. Significance of test results are determined based on the value of $p<0.05$.The results showed that there are significant effect of PBL method to the value of the Family Planning materials written test considering to previously semester IP (First Semester IP) $(p=0.001)$, no influence of PBL method to SDL ( $p=0.548)$, no significant relationship between tutor evaluation to the value of Family Planning materials written test $(\mathrm{p}=0.360)$, significant relationship between tutor evaluation with SDL capability $(\mathrm{p}=0.000)$, with a correlation value 0,559 which showed a positive correlation with moderate correlation strength.The conclusion is the implementation of PBL method affect the value of a written test, PBL method does not relate to the ability of SDL student, tutor performance is not related to the value of a written test, but relates to the ability of SDL students. PBL method needs to be applied to the Family Planning material and other subjects, as well as the implementation of a more optimal tutor training, intensive and continuous.
\end{abstract}

Keywords: Problem-based learning, learning outcomes, the value of a written test, self-directed learning, tutor performance

\section{Pendahuluan}

Bidan sebagai mitra perempuan merupakan profesi yang memiliki pekerjaan dengan kompleksitas dan tanggung jawab yang besar.Untuk menyiapkan bidan yang tanggap terhadap situasi terkini dan dapat mengatasi berbagai situasi kompleks yang dihadapi perempuan sepanjang siklus reproduksinya serta bayi dan balita sehat, dibutuhkan bidan yang mampu berpikir kritis, melakukan analisissintesis, advokasi dan kepemimpinan. Dengan demikian, bidan diharapkan mampu memberikan pelayanan yang lebih baik untuk melindungi masyarakat dan dapat bersaing dalam era global. ${ }^{1}$

Upaya yang dapat dilakukan adalah dengan diselenggarakannya pendidikan kebidanan oleh institusi dalam suatu program pendidikan Diploma III Kebidanan. Mengacu kepada Surat Keputusan Menteri Pendidikan Nasional Nomor: 232/U/2000, tentang "Pedoman Penyusunan Kurikulum Pendidikan Tinggi dan Penilaian Hasil Belajar Mahasiswa", serta Peraturan Pemerintah Republik Indonesia Nomor 19 Tahun 2005 tentang "Standar Nasional Pendidikan", diharapkan pendidikan bidan dapat menerapkan kurikulum berbasis kompetensi, yang dikembangkan berdasarkan standar kompetensi profesi dalam melaksanakan tugasnya. ${ }^{2}$

Perubahan paradigma metode pembelajaran berpusat pada peserta didik telah diterapkan pada beberapa perguruan tinggi baik di dunia maupun di Indonesia.Berbagai metode telah banyak 
Rani Sumarni: Pengaruh Implementasi Metode Problem Based Learning terhadap hasil belajar materiKeluarga Berencana (Dalam Mata Kuliah Kesehatan Reproduksi dan KeluargaBerencana I pada Program Studi Kebidanan (D3) STIKes Jenderal Achmad Yani Cimahi TA.2014/2015)

ditemukan oleh para peneliti pendidikan., Pendidik harus bisa menentukan metode yang relevan terhadap suatu mata kuliah. Melatih berpikir analitis, kreatif, berpikir kritis dan manajemen waktu dapat dilakukan melalui pendekatan Student Center Learning (SCL) yang salah satunya dengan menggunakan metode PBL. ${ }^{3}$

PBL atau pembelajaran berbasis masalah adalah suatu pendekatan pembelajaran yang menggunakan masalah dunia nyata sebagai suatu konteks bagi mahasiswa untuk belajar tentang cara berpikir kritis dan keterampilan pemecahan masalah, serta untuk memperoleh pengetahuan dan konsep yang esensial dari materi perkuliahan. Dengan membuat permasalahan sebagai tumpuan pembelajaran, mahasiswa didorong untuk mencari informasi yang diperlukan untuk menyelesaikan masalah. ${ }^{4}$

Pembelajaran mandiri atau SDLmerupakan salah satu prinsip pembelajaran yang digunakan dalam PBL selain berprinsip konstruktif, kolaboratif, dan kontekstual. Melalui prinsip pembelajaran mandiri ini maka peserta didik dapat berperan aktif dalam setiap pembelajaran serta menumbuhkan keinginan untuk selalu belajar sepanjang hayat (long life learning) sehingga mereka akan terus berusaha untuk mendapatkan ilmu baru. ${ }^{5}$

Sekolah Tinggi Ilmu Kesehatan Jenderal Achmad Yani Cimahi merupakan salah satu institusi penyelenggara pendidikan kesehatan, yang diantaranya memiliki Program Studi Kebidanan Diploma III.Program studi ini belum melaksanakan PBL dalam strategi pembelajarannya.Program pengajaran yang selama ini berlangsung masih mengacu kepada Teacher Centered Learning (TCL).

Dalam kurikulum D-III Kebidanan terdapat mata kuliah Kesehatan Reproduksi dan Keluarga Berencana 1 (Kespro-KB 1) yang ditempatkan pada semester ganjil dengan bobot 3 Satuan Kredit Semester (SKS), yang terdiri dari 2 SKS Teori dan 1 SKS Praktek, bertujuan untuk memberikan kemampuan kepada mahasiswa untuk memahami konsep, hak-hak kesehatan reproduksi, faktor-faktor yang memengaruhi kesehatan reproduksi, upaya pencegahan, dan deteksi dini, serta memberikan asuhan KB.

Hasil belajar merupakan perubahan perilaku individu yang meliputi ranah kogntif, afektif, dan psikomotor. Perubahan perilaku tersebut diperoleh setelah peserta didik menyelesaikan program pembelajarannya melalui interaksi dengan berbagai sumber belajar dan lingkungan belajar. $^{6}$

Berdasarkan data laporan Proses Belajar Mengajar (PBM), terjadi penurunan tingkat kelulusan pada Mata Kuliah Kespro-KB I, yaitu 83 persen pada TA.2012/2013 menjadi 78 persen pada TA.2013/2014.Berdasarkan data yang telah disampaikan maka sesuai dengan yang diamanatkan dalam Standar Nasional Pendidikan, diperlukan upaya-upaya yang dapat dilakukan untuk meningkatkan kemampuan belajar peserta didik yang lebih optimal.

Salah satu upaya yang dapat dilakukan, yaitu dengan menerapkan SCL melalui metode pembelajaran PBL. Dalam penelitian ini metode PBL diterapkan pada materi Keluarga Berencana yang merupakan sebagian dari substansi Mata Kuliah Kespro-KB I, yang meliputi materi metode kontrasepsi sederhana dan modern. Dalam pelaksanaannya, dilakukan pula evaluasi kinerja tutor sebagai salahsatu upaya monitoring dalam pelaksanaan PBL.

Dalam kurikulum PBL, peran dosen sebagai tutor sangat berbeda dari peran dosen dalam pembelajaran konvensional. Tutor merupakan fasilitator diskusi yang salah satu perannya mengarahkan peserta didik untuk mampu belajar secara mandiri. Tutor tidak mengajar sebagai seorang ahli, namun tutor harus mampu memfasilitasi peserta didik untuk mampu berinteraksi, bekerja sama dalam mengekplorasi masalah pemicu yang ada. Karena peran fasilitatif dari tutor, tingkat keahlian konten tutor, secara teoritis, seharusnya tidak memengaruhi kinerja siswa dalam model PBL. Howard Barrows, mengemukakan keterampilan tutor dalam memfasilitasi tutorial lebih penting dibanding dengan keahlian dalam bidang ilmu nya. ${ }^{7}$ Demikian pula, Chng dkk menemukan bahwa kinerja tutor dalam memfasilitasi proses tutorial memberikan dampak yang signifikan terhadap prestasi belajar mahasiswa. ${ }^{8}$

Tujuan penelitian ini adalah untuk mengetahui pengaruh implementasi PBL terhadap hasil belajar mahasiswa serta kaitannya dengan IP Semester I, SDL dan kinerja tutor.

\section{Metode}

Penelitian ini menggunakan rancangan preeksperimental dengan pendekatan kuantitatif, menggunakan desain intact group 
Rani Sumarni: Pengaruh Implementasi Metode Problem Based Learning terhadap hasil belajar materiKeluarga Berencana (Dalam Mata Kuliah Kesehatan Reproduksi dan KeluargaBerencana I pada Program Studi Kebidanan (D3) STIKes Jenderal Achmad Yani Cimahi TA.2014/2015)

comparison.Jumlah sampel dalam penelitian ini adalah 123 mahasiswa, terbagi dalam kelompok perlakuan dan kelompok kontrol.Penentuan kelompok tersebut dilakukan dengan acak sederhana. Kelompok perlakuan 44 mahasiswa, kempok kontrol 79 mahasiswa.Kriteria eksklusi penelitian ini adalah kehadiran mengikuti proses pembelajaran $<100$ persen, pernah tinggal kelas, peserta ujian susulan, peserta ujian dalam keadaan sakit. Variabel hasil belajar, yaitu nilai ujian tulis dan SDL diukur setelah dilakukan pembelajaran materi KB.Pengambilan data dilakukan dengan menggunakan instrumen berupa soal dan kuesioner yang sudah dilakukan uji validitas dan reliabilitas.Kelompok perlakuan dilakukan pembelajaran dengan metode PBL sedangkan kelompok kontrol dilakukan pembelajaran dengan metode Ceramah Tanya Jawab (CTJ).Perbedaan IP Semester I dan nilai ujian tulis dianalisis dengan mengunakan uji $t$ tidak berpasangan. Sedangkan perbedaan nilai SDl dianalisis dengan menggunakan uji MannWhitney,sedangkan pengaruh implementasi metode PBL terhadap hasil belajar dianalisis dengan regresi logistikberganda.Penelitian dilakukan pada bulan Februari-Maret 2015.

Penelitian ini telah melalui persetujuan etikFakultas Kedokteran UniversitasPadjadjaran.Pelaksanaan penelitian ini dilakukan dengan mempertimbangkan aspek etik yaitu, keadilan, kerahasiaan dan menghargai martabat responden.

\section{Hasil}

Tabel1Distribusi Data Variabel IP Semester I, SDL, dan Nilai Ujian Tulis Materi Keluarga Berencana

\begin{tabular}{|c|c|c|c|c|c|}
\hline \multirow[b]{2}{*}{ Variabel } & \multirow[b]{2}{*}{ Kelompok } & \multicolumn{3}{|c|}{ Ukuran Statistik } & \multirow{2}{*}{$\begin{array}{c}\text { Uji } \\
\text { Normalita } \\
\text { s data } \\
(\text { nilai } p)^{*}\end{array}$} \\
\hline & & Rerata (SD) & Median & Rentang & \\
\hline \multirow[t]{2}{*}{ IP Semester I } & PBL & $2,98(0,29)$ & 2,94 & $2,25-3,63$ & 0.990 \\
\hline & Non PBL & $3,11(0,33)$ & 3,13 & $2,25-3,75$ & 0,437 \\
\hline \multirow[t]{2}{*}{ SDL } & PBL & $65,09(7,34)$ & 65,00 & $43-80$ & 0,454 \\
\hline & Non PBL & $66,43(6,43)$ & 65,00 & $54-82$ & 0,035 \\
\hline \multirow[t]{2}{*}{ NilaiUjian Tulis } & PBL & $72,23(5,67)$ & 72,90 & $58,60-88,60$ & 0,571 \\
\hline & Non PBL & $68,72(7,89)$ & 69,30 & $50,00-85,80$ & 0,565 \\
\hline
\end{tabular}

Keterangan $: *)$ Nilai $p$ dihitung berdasarkan uji Shapiro-Wilk

Berdasarkan tabel 1 diketahui data variabel IP semester I dan variabel nilai ujian tulis, berdistribusi normal (nilai $p>0,05$ ) maka pengujian statistik selanjutnya menggunakan uji parametric, sedangkan untuk variabel SDL pada kelompok non PBL, datanya berdistribusi tidak normal (nilai $p<0,05$ ), sehingga untuk pengujian statistik selanjutnya menggunakan uji non parametrik.

Tabel 2Hasil IP Semester I, SDL, dan Nilai Ujian Tulis pada Kelompok PBL dan nonPBL

\begin{tabular}{|c|c|c|c|c|}
\hline \multirow{2}{*}{\multicolumn{2}{|c|}{ Variabel }} & \multicolumn{2}{|c|}{ Kelompok } & \multirow[b]{2}{*}{$\begin{array}{l}\text { Nilai } \\
p\end{array}$} \\
\hline & & $\begin{array}{c}\text { PBL } \\
(\mathrm{n}=43)\end{array}$ & $\begin{array}{c}\text { Non PBL } \\
(\mathrm{n}=77)\end{array}$ & \\
\hline \multicolumn{5}{|c|}{ 1. IP Semester 1} \\
\hline & Rerata (SD) & $2,98(0,29)$ & $3,10(0,33)$ & \multirow{2}{*}{$0,042^{*}$} \\
\hline & Rentang & $2,25-3,63$ & $2,25-3,75$ & \\
\hline \multicolumn{5}{|c|}{ 2. SDL } \\
\hline & Rerata (SD) & $65,09(7,34)$ & $66,43(6,43)$ & \multirow{3}{*}{$0,548 * *$} \\
\hline & Median & 65,00 & 65,00 & \\
\hline & Rentang & $43-80$ & $54-82$ & \\
\hline \multicolumn{5}{|c|}{ 3. Nilai Ujian Tulis } \\
\hline & Rerata (SD) & $72,23(5,67)$ & $68,72(7,89)$ & \multirow{2}{*}{$0,012 *$} \\
\hline & Rentang & $58,60-88,60$ & $50,00-85,8$ & \\
\hline
\end{tabular}


Rani Sumarni: Pengaruh Implementasi Metode Problem Based Learning terhadap hasil belajar materiKeluarga Berencana (Dalam Mata Kuliah Kesehatan Reproduksi dan KeluargaBerencana I pada Program Studi Kebidanan (D3) STIKes Jenderal Achmad Yani Cimahi TA.2014/2015)

Berdasarkan tabel 2 diketahui terdapat perbedaan rerata IP semester I yang bermakna antara kelompok PBL dan non PBL dimana rerata IP semester I pada kelompok non PBL lebih tinggi dibandingkan dengan kelompok PBL, terdapat perbedaan rerata nilai ujian tulis yang bermakna antara kelompok PBL dan non PBL dimana rerata nilai ujian tulis pada kelompok PBL lebih tinggi dibandingkan dengan kelompok non PBL dan diketahui nilai SDL tidak berbeda pada kedua kelompok, dimana rerata nilai SDL pada kelompok non PBL lebih tinggi dibandingkan dengan kelompok PBL.

Tabel 3Perbedaan Nilai Ujian Tulis antara Kelompok PBL dan non PBL dengan IP Semester I sebagai Kovariat

\begin{tabular}{ccc}
\hline \multicolumn{1}{c}{ Kelompok } & Rerata (SD) & IK 95 \% (Rerata) \\
\hline PBL $(\mathrm{n}=43)$ & $72,82(1,05)$ & $70,75-74,90$ \\
Non PBL $(\mathrm{n}=77)$ & $68,39(0,78)$ & $66,84-69,93$ \\
\hline Keterangan:Nilai F hitung $=11,35$, dengan nilai $p=0,001$
\end{tabular}

Tabel 3 menunjukkan IP memengaruhi terhadap perbedaan hasil belajar antara kelompok PBL dan non PBL.Terdapat perbedaan nilai ujian tulis antara kelompok PBL dan non PBL setelah memasukkan IP semester I sebagai kovariat.

Tabel 4Pengaruh metode PBL dan IP Semester I terhadap Nilai Ujian Tulis

\begin{tabular}{|c|c|c|c|c|}
\hline Variabel & $\begin{array}{c}\text { Koefisien } \\
\text { B }\end{array}$ & $\begin{array}{l}\text { SD } \\
\text { (B) }\end{array}$ & $\begin{array}{c}\mathrm{t} \\
\text { hitung }\end{array}$ & Nilai $p$ \\
\hline IP & & 1,956 & 3,82 & \\
\hline $\begin{array}{l}\text { Semester } \\
1\end{array}$ & 7,484 & & & $<0,001$ \\
\hline $\begin{array}{l}\text { Metode } \\
\text { Belajar* }\end{array}$ & 4,437 & 1,317 & 3,369 & 0,001 \\
\hline Konstanta & 45,458 & - & - & - \\
\hline
\end{tabular}

Dari hasil analisis regresi multipel diperoleh persamaan regresi bahwa nilai ujian tulis $=45$, $458+7,484$ x IP Semester I + 4,437 x Metode Belajar. IP Semester I berperan terhadap peningkatan nilai ujian tulis. Sebesar $15,8 \%$ variasi dari nilai ujian tulis dipengaruhi oleh IP Semester I dan metode belajar. Semakin tinggi nilai IP Semester 1 dan penerapan metode PBL maka nilai ujian tulis semakin meningkat. Hasil ini menunjukkan bahwa ada variasi lainnya (sebesar $84,2 \%$ ) dipengaruhi oleh faktor-faktor lain yang tidak diteliti dalam penelitian ini.

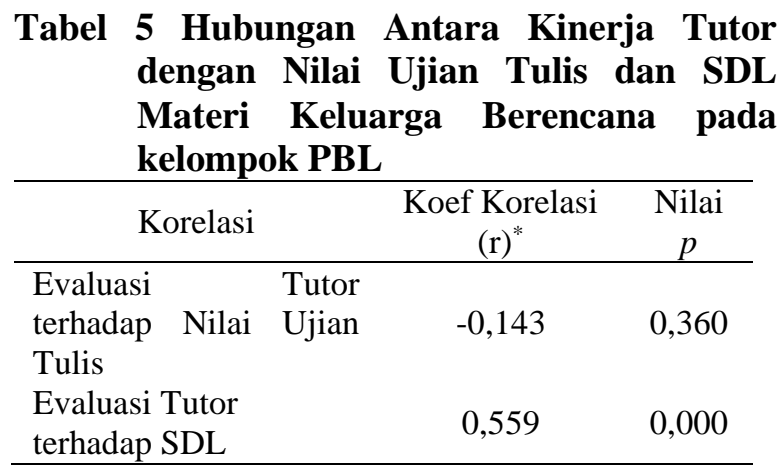

Keterangan :*) Nilai $p$ dihitung berdasarkan uji

KoefisienKorelasi Pearson

Tabel 5 menunjukkan terdapat hubungan yang bermakna antara evaluasi tutor dengan kemampuan SDL mahasiswa, nilai korelasi 0,559 menunjukkan korelasi positif dengan kekuatan korelasi sedang. Data lainnya menunjukkan bahwa tidak ada hubungan antara evaluasi tutor dengan nilai ujian tulis.

\section{Pembahasan}

Penelitian ini menunjukkan IP semester Ipada kelompok non PBL lebih tinggi dibandingkan dengan kelompok PBL. Namun demikian, rerata nilai ujian tulis pada kelompok PBL lebih tinggi dibandingkan dengan rerata nilai ujian tulis pada kelompok non PBL, serta diketahui pula bahwa terdapat pengaruh implementasi metode PBL terhadap nilai ujian tulis materi $\mathrm{KB}$ dengan mempertimbangkan IP semester I sebagai kovariat $(p=0,001)$.

Pelaksanaan ujian tulis dalam penelitian ini menggunakan soal vignette sehingga mendorong mahasiswa untuk lebih meningkatkan kemampuan analisis dan problem solving yang dimiliki untuk mampu menjawab setiap pertanyaan.Hal ini menunjukkan fenomena bahwa peningkatan kemampuan kognitif mahasiswa lebih tinggi terjadi pada kelompok PBL dibandingkan dengan kelompok non PBL. Berdasarkan uraian tersebut, semakin disempurnakannya pene-rapan metode PBL khususnya pada materi Keluarga Berencana maka ada harapan hasil belajar mahasiswa akan semakin meningkat.

Efektivitas implementasi metode PBL dipengaruhi oleh 3 faktor utama, yaitu faktor kasus, mahasiswa, dan tutor. ${ }^{9}$ Smith, dalam 
Rani Sumarni: Pengaruh Implementasi Metode Problem Based Learning terhadap hasil belajar materiKeluarga Berencana (Dalam Mata Kuliah Kesehatan Reproduksi dan KeluargaBerencana I pada Program Studi Kebidanan (D3) STIKes Jenderal Achmad Yani Cimahi TA.2014/2015)

teorinya mengemukakan PBL meningkatkan kecakapan pemecahan masalah, lebih mudah mengingat, meningkatkan pemahaman, meningkatkan pengetahuan yang relevan dengan dunia praktik, kemampuan analisis, membangun kemampuan kepemimpinan dan kerjasama, kecakapan belajar, dan memotivasi diri sehingga dapat berpengaruh terhadap peningkatan prestasi belajar. ${ }^{10}$

Pengetahuan dapat terbentuk dengan tingkat retensi yang baik apabila mahasiswa mampu mengaktifkanPrior Knowledge (PK), dan menggabungkan serta menyesuaikan dengan informasi baru yang didapat. Kasus pemicu atau skenario klinik yang berkenaan dengan masalah di dunia nyata akan mempercepat munculnya kemampuan analisis klinik (clinical reasoning) atau kemampuan menyelesaikan masalah.PK mempunyai implikasi yang sangat kuat dalam interaksi dengan tugas-tugas dan pembelajaran. Hal ini sangat sesuai dengan proses pembelajaran dalam PBL. Hal lain yang perlu diperhatikan dalam kaitannya dengan PK dan PBL adalah adanya lingkungan yang kondusif, termasuk kemampuan fasilitator dalam mengendalikan tutorial. $^{11}$

Hasil lain dalam penelitian ini adalah IP Semester I berperan terhadap peningkatan nilai ujian tulis. Sebesar 15,8\% variasi dari nilai ujian tulis dipengaruhi oleh IP Semester I dan metode belajar. Semakin tinggi nilai IP Semester 1 dan penerapan metode PBL maka nilai ujian tulis semakin meningkat. Hasil ini menunjukkan pula bahwa ada variasi lainnya (sebesar 84,2\%) dipengaruhi oleh faktor-faktor lain yang tidak diteliti dalam penelitian ini. Hasil tersebut sejalan dengan penelitian Dick \& Carey, bahwa perilaku awal (entry behaviour) yaitu kemampuan dan/atau keterampilan khusus yang sudah dikuasai oleh sekelompok siswa sebelum memulai suatu pembelajaran yang baru dapat mempengaruhi pelajaran selanjutnya. ${ }^{11}$

Hasil penelitian ini sesuai dengan penelitian lain yang dilakukan Wulandari di Jambi, yang menunjukkan adanya perbedaan rata-rata hasil belajar sehingga dinyatakan terdapat pengaruh metode pembelajaran terhadap hasil belajar. Hasil belajar mahasiswa yang menggunakan metode PBL, lebih tinggi daripada hasil belajar mahasiswa yang menggunakan metode konvensional. Adapun penilaian non-tes yang dilakukan selama pembelajaran, yaitu penilaian sikap yang mencakup keaktifan, komunikasi, dan kerjasama, diperoleh hasil penilaian sikap pada kelas PBL lebih tinggi daripada kelas konvensional yaitu rata-rata 4,0 untuk kelas PBL dan 3,2 untuk kelas konvensional. ${ }^{12}$

Dalam penelitian ini, diukur pula salah satu soft skill mahasiswa, yaitu kemampuan Self Directed Learning (SDL) yang dilakukan setelah intervensi. Hasil penelitian menujukkan bahwa SDL pada kelompok PBL dan non PBL tidak berbeda secara bermakna. Pada kelompok non PBL yang masih menggunakan prinsip pembelajaran teacher centered learning, terlihat kemampuan SDL mahasiswa lebih tinggi dibandingkan dengan kelompok PBL.

Berdasarkan hasil identifikasi dan analisis variabel lain dalam penelitian ini, maka penjelasan yang dapat disampaikan adalah bahwa untuk menunjukkan kemampuan SDL yang lebih tinggi, bukan hanya dipengaruhi oleh proses pembelajaran saja, tetapi juga dipengaruhi oleh faktor-faktor lain termasuk upaya yang dilakukan untuk meningkatkan kemampuan SDL.

SDLdiperlukan mahasiswa untuk mengerjakan

tugas,mengkombinasikanperkembangan

kemampuan dengan perkembangan karakter dan mempersiapkan diri untuk mampu mempelajari seluruh kehidupan mereka, sehinggasetelah mahasiswa menyelesaikan pendidikannya, akan tumbuh sikap inisiatif yang tinggi serta terus berupaya untuk belajar selama kehidupannya. ${ }^{5}$

Hasil penelitian ini dapat disebabkan karena metode PBL baru diterapkanpertamakalipada materi Keluarga Berencana yang merupakan bagian dari Mata Kuliah Kespro-KB I yang berlangsung selama 4 minggu.Pembelajaran dalam keseluruhan kurikulum masih didominasi oleh metode konvensional, implementasi PBL diterapkan 3 kali(8jam)/minggu.Mahasiswa belum terbiasa dengan metode PBL sehingga pembelajaran mandiri yang merupakan prinsip pembelajaran PBL belum terinternalisasi. Penyebab lain yang teridentifikasi adalah bahwa Indeks Prestasi Semester mahasiswa pada kelompok non PBL lebih tinggi daripada kelompok PBL. Tentu hal ini dapat mempengaruhi kemampuan SDL seseorang.

SDLdapat terjadi dalam banyak situasi yang bervariasi, mulai dari ruangan kelas yang berfokus pada guru secara langsung (teacherdirected) hingga belajar dengan perencanaan siswa sendiri (self planned) dan dilakukan sendiri (self conducted). Guglielmino, lebih lanjut 
Rani Sumarni: Pengaruh Implementasi Metode Problem Based Learning terhadap hasil belajar materiKeluarga Berencana (Dalam Mata Kuliah Kesehatan Reproduksi dan KeluargaBerencana I pada Program Studi Kebidanan (D3) STIKes Jenderal Achmad Yani Cimahi TA.2014/2015)

menyatakan tentang karakteristik yang dimiliki oleh pelajar, yakni sikap, nilai, kepercayaan, dan kemampuan yang akhirnya menentukan apakah SDL terjadi pada suatu situasi belajar. ${ }^{13}$

Menurut Knowles, pentingnya SDL dalam proses pembelajaran didasarkan pada dua hal yaitu orang-orang yang memiliki inisiatif sendiri dalam belajar akan terus belajar dan akan lebih baik dalam belajar bila dibandingkan dengan orang yang tidak memiliki inisiatif dalam belajar, lalu mereka juga akan secara belajar secara lebih mendalam dan menetap. ${ }^{13}$

Kemampuan SDL pada metode PBL dapat terbentuk dengan baik apabila mahasiswa memiliki motivasi untuk melakukannya. Motivasi dapat berasal dari internal maupun eksternal individu mahasiswa tersebut. ${ }^{14}$ Dalam penelitian ini SDL diukur melalui kuesioner yang diisi oleh mahasiswa sendiri.Penelitian ini tidak mengukur motivasi mahasiswa, baik motivasi internal maupun eksternal, serta tidak dilakukan pengukuran terhadap kemampuan SDL sebelum penerapan metode PBL.

Menurut Secondira, dkk bahwa faktor terbesar yang mempengaruhi mahasiswa melakukan kegiatan pembelajaran adalah faktor mahasiswa $(28,41 \%)$ yang salah satunya faktor motivasi instrisik $(21,34 \%)$ mempengaruhi pembelajaran mandiri. Jika mahasiswa memiliki motivasi dan keinginansendiriuntuk mendapatkan informasi dan pengetahuan yang relevan, maka pembelajaran mandiri dalam PBL akan terlaksana dengan baik. ${ }^{15}$ Hasil penelitian ini sejalan dengan penelitian yang dilakukan Musal, et al bahwa mahasiswa tahun pertama lebih banyak menghabiskan waktu belajar mandirinya dibandingkan mahasiswa tahun ketiga. ${ }^{16}$

Dalam penelitian ini, dilakukan pula pengukuran kinerja tutor melalui penilaian yang diberikan oleh mahasiswa pada kelompok PBL dengan mengisi kuesioner. Hasil penelitianmenunjukkan bahwa tidak ada hubungan yang bermakna antara kinerja tutor dengan nilai ujian tulis (nilai $p \quad 0,360>$ 0,05).Halini dapat disebabkan karena implementasi pembelajaran PBLbaru pertama kali dilaksanakan. Dosen yang bertugas sebagai tutor dalam penelitian ini sudah menjalani pelatihan tutorial, namun pelatihan yang telah dilaksanakan terbatas hingga tahap simulasi, dan tidak dilakukannya sit in dan evaluasi melalui proses tandem (pendampingan dan dievaluasi oleh para ahli) untuk mendapatkan pengalaman yang lebih nyata serta penentuan tingkat kompetensi tutor

Tutor memiliki peran yang penting dalam proses tutorial. Penampilan atau kinerja tutor merupakan kemampuan kerja yang ditampilkan ketika menjalankan peranannya sebagai fasilitator dalam proes tutorial, yaitu menerapkan prinsip-prinsip pembelajaran pada proses PBL (konstruktif, kolaboratif, mandiri, dan kontekstual). Tutorharus mampu mendorong mahasiswa untuk melakukan curah pendapat dan memecahkan masalah, membantu mengembangkan mahasiswa untuk berpikir kritis, mendorong mahasiswa untuk saling berbagi pengetahuan yang sudah dimiliki sebelumnya, mendorong mahasiswa untuk meningkatkan kemampuan bekerja sama untuk memecahkan masalah, membantu mengembangkan kemampuan berkomunikasi aktif, membantu mengembangkan kemampuan diri mahasiswa. ${ }^{7}$

Implementasi metode PBL juga berpengaruh terhadap nilai ujian tulis, menunjukkan bahwa efektivitas implementasi metode PBL bukan hanya dipengaruhi oleh kinerja tutor, namun ada faktor lain yang mempengaruhi seperti kualitas kasus pemicu dan kemampuan/kinerja mahasiswa. ${ }^{9}$ Namun, dalam penelitian ini tidak diteliti lebih jauh pengaruh faktor-faktor lain tersebut terhadap hasil belajar mahasiswa pada kelompok PBL.

Kaufman, dalam teorinya mengemukakan bahwa sebagian besar kontrol proses belajar berada pada mahasiswa sendiri, sehingga faktor mahasiswa sangat berpengaruh terhadap pelaksanaan metode PBL, yangkedepannya berdampak pada hasil belajar mahasiswa tersebut. ${ }^{17}$ Mahasiswa harus memiliki rasa tanggungjawab dalam belajar sehingga mahasiswa harus mampu menginisiasi dan mengatur kebutuhan belajarnya sendiri serta menjadi motivator belajar bagi diri sendiri dan orang lain.

Hasil penelitan ini sejalan dengan penelitian Schmidt et al tentang peran tutor dalam PBL, bahwa tidak ada pengaruh tutor "content expert" terhadap pencapaian keberhasilan belajar mahasiswa karena tutor yang efektif adalah tutor yang mampu berperan sebagai fasilitator dan juga mampu berperan sebagai pakar yang baik (content expert). ${ }^{18}$

Hasil lainnya yang diperoleh dalam penelitian ini adalah bahwa terdapat hubungan yang positif antara kinerja tutor dengan SDL 
Rani Sumarni: Pengaruh Implementasi Metode Problem Based Learning terhadap hasil belajar materiKeluarga Berencana (Dalam Mata Kuliah Kesehatan Reproduksi dan KeluargaBerencana I pada Program Studi Kebidanan (D3) STIKes Jenderal Achmad Yani Cimahi TA.2014/2015)

mahasiswa pada kelompok PBL $(p<0,05)$. Hasil tersebut dapat disebabkan perbedaan lingkungan belajar yang konstruktivis yang terbentuk dalam proses PBL, mahasiswa memiliki kemampuan dalam memotivasi dirinya untuk belajar mandiri, kendali diri untuk belajar yang baik serta kemampuan meminimalkan kecemasan selama mengikuti kegiatan tutorial, juga menjadi faktor yang berperan terhadap kegiatan belajar mandiri mahasiswa yang lebih baik.

Pada proses PBL yang berkaitan dengan prinsip pembelajaran mandiri, tutor memfasilitasi mahasiswa untuk mampu menentukan tujuan pembelajarannya sendiri melalui kasus pemicu yang ada, kemudian mahasiswa didorong untuk mampu mencari informasi tambahan yang relevan dariberbagai macam sumber pengetahuan yang ada.Keluasan, keberagaman, dan relevansi informasi yang diperolehmahasiswa pada saat belajar mandiri, akan menentukan pemahaman mahasiswa terhadap tujuan belajar yangdicapai. ${ }^{7,19}$

Hasil penelitian ini sejalan dengan penelitian Martinus et al mengenai Pengaruh Kinerja Tutor Terhadap Kemandirian Belajar Mahasiswa dalam PBL, yang menyatakan bahwa kegiatan belajar mandiri dan pelaporan hasil belajar mandiri mahasiswa akan semakin baik bila kinerja tutor semakin tinggi. ${ }^{20}$

\section{Simpulan}

Implementasi metode PBL berpengaruh terhadap nilai ujian tulis, metode PBL tidak berhubungan dengan kemampuan SDL mahasiswa, kinerja tutor tidak berhubungan dengan nilai ujian tulis namun berhubungan dengan kemampuan SDL mahasiswa

\section{Daftar Pustaka}

1. Keputusan Menteri Kesehatan RI tentang Standar Pofesi Bidan, Stat. No.369/Menkes/SK/III/2007 (2007).

2. Keputusan Mendiknas RI No.45/U/2002 Tentang Kurikulum Inti Pendidikan Tinggi, (2002).

3. Jaafar R, Rashid FA, Rahim AFA, Arzuman H, Yusoff MSB. Student-Centered Learning (SCL) Approaches for Innovative Teaching: Centre for Develoment of Academic Excellence (CDAE), USM; 2012.

4. Amin Z, Hoon Eng K. Basics in Medical Education. Singapore: World Scientific Publishing Co.Pte.Ltd; 2003.p213-247.
5. Murad MH, Coto-Yglesias F, Varkey P, Prokop LJ, Murad AL. The effectiveness of self-directed learning in health professions education: a systematic review. Medical Education. 2010;44(11):1057-68.

6. Arifin Z. Evaluasi Pembelajaran. Bandung: PT Remaja Rosdakarya; 2009.p7-16.

7. Walsh A. The Tutor in Problem Based Learning: A Novice's Guide. 2005: Available from: fhs.mcmaster.ca/facdev/documents/tutorPBL.pdf.

8. Chng E, Yew EHJ, Schmidt HG. Effects of tutor-related behaviours on the process of problem-based learning. Advances in Health Sciences Education. 2011;16(4):491-503.

9. Dolmans DH, Grave WD, Wolfhagen IH, Van Der Vleuten CP. Problem-based learning: future challenges for educational practice and research. Medical Educatin. 2005;39:732-41.

10. Amir MT. Inovasi Pendidikan Melalui Problem Based Learning. Jakarta: Kencana Prenada Media Group; 2010.p27-9.

11. Hansberger JT, Holt RW. The Effects of Prior Knowledge on Goal Variability \& Learning: The More Goals the Merrier. Proceedings of the Human Factors and Ergonomics Society Annual Meeting. 2002 September 1, 2002;46(12):958-62.

12. Wulandari, Sjarkawi, M D. Pengaruh Problem Based Learning dan Kemampuan Mahasiswa Berpikir Kritis terhadap Hasil Belajar Mahasiswa. Tekno-Pedagogi. 2011;1(1):14-24.

13. Loyens SM, Magda J, Rikers RJP. Self-Directed Learning in Problem-Based Learning and its Relationships with Self-Regulated Learning. Educ Psychol Rev. 2008 2008/12/01;20(4):411-27.

14. Hartono B. Self Directed Learning dalam Problem Based Learning di FK UKRIDA. Jurnal Kedokteran Meditek. 2014; 18 (48).

15. Secondira VM, Retno GR, Suhoyo Y. Faktor-Faktor yang Mempengaruhi Mahasiswa Fakultas Kedokteran Universitas Gadjah Mada untuk Melaksanakan Pembelajaran yang Konstruktif, Mandiri, Kolaboratif, dan Konstekstual dalam Problem Based Learning. Jurnal Pendidikan Kedokteran dan Profesi Kesehatan Indonesia. 2009;4:34-45.

16. Musal B, Gursel Y, Taskiran HC, Ozan S, Tuna A. Perceptions of first and third year medical students on self-study and reporting processes of problem-based learning. BMC Medical Education. 2004;4:16.

17. Cantillon P, Hutchinson L, Wood D. ABC Of Learning and Teaching in Medicine. London: BMJ Publishing Group; 2003.

18. Maudsley G. Roles and responsibilities of the problem based learning tutor in the undergraduate medical curriculum. BMJ : British Medical Journal. 1999;318(7184):657-61.

19. Abdalla ME, Gaffar AM. The Seven Steps oF PBL Implementation: Tutor's Manual. Jazan-KSA.2011.

20. Martinus GRR, O.Emilia. Pengaruh Kinerja Tutor Terhadap Kemandirian Belajar Mahasiswa dalam Problem Based Learning di Fakultas Kedokteran UISU. Jurnal Pendidikan Kedokteran Indonesia. 2012;1:p.193-9. 